\title{
Relationship Between Accessibility to Polling Places and Electoral
} \section{Abstention}

\author{
Diego Escobar ${ }^{1}$, Santiago Cardona ${ }^{1} \&$ Carlos Moncada $^{2}$ \\ ${ }^{1}$ Universidad Nacional de Colombia, Sede Manizales. Facultad de Ingeniería y Arquitectura, Departamento de \\ Ingeniería Civil, Carrera 27 \# 64-60, Manizales, 170004, Colombia \\ ${ }^{2}$ Universidad Nacional de Colombia, Sede Bogotá. Facultad de Ingeniería, Departamento de Ingeniería Civil y \\ Agrícola, Ciudad Universitaria edificio 417 oficina 417, Bogotá, 111321, Colombia \\ Correspondence: Diego Escobar, Universidad Nacional de Colombia, Sede Manizales. Facultad de Ingeniería y \\ Arquitectura, Departamento de Ingeniería Civil, Carrera 27 \# 64-60, Manizales, 170004, Colombia. E-mail: \\ daescobarga@unal.edu.co
}

Received: June 6, 2018

Accepted: June 24, $2018 \quad$ Online Published: August 8, 2018

doi:10.5539/mas.v12n9p7

URL: https://doi.org/10.5539/mas.v12n9p7

\begin{abstract}
One of the great factors to define the consolidation of democracy in the countries is to measure the percentage of electoral participation. For this reason, reducing abstention in electoral processes by increasing participation is one of the great challenges for the different countries that seek to move to full democracy. In this sense, Colombia has had a historical abstention of over $50 \%$ (period 1978 - 2018), which can be explained by various reasons such as the presence of the armed conflict or the remote location of some polling places. For this reason, this research seeks to analyze the location of the polling places in the urban area of Manizales and Villamaría, in order to quantify their accessibility through the pedestrian network and look at the population coverage, using the integral accessibility and the ordinary Kriging method as a predictive statistical geo method for the construction of the isochronous travel time curves.
\end{abstract}

Keywords: integral accessibility, walk, polling places, electoral abstention

\section{Introduction}

Democracy is a system of government where citizens choose those rulers who represent them in the conduction of the country. It is seen as a form of free and universal participation as well as a method of participation that creates a framework of equality among the inhabitants, always framing the same rules of the game for everyone (Levine \& Molina, 2007), where there is a clear difference between political participation and electoral participation, both expressions of democracy (Nohlen, 2004). The first one is understood as different citizen actions of participation in events focused on democracy as political manifestations, collection of signatures, among others (Nohlen, 2004). While the electoral participation, which although derived from the latter, is much more important because it shows the opinion of the majority of the population in an egalitarian way through the vote (Nohlen, 2004). The phenomenon of abstentionism is understood according to Nohlen, Zovatto, Orozco and Thompson (2007) "... as the non-participation in the act of voting among those who are entitled to it...", generating an indicator showing the percentage of people who did not participate in the electoral process (Nohlen, Zovatto, Orozco, \& Thompson, 2007). In addition, this has been used by various researchers to measure the quality of democracy in countries (Levine \& Molina, 2007) which, added to different variables, show the consolidation and legitimacy of this system of government (Alcántara, 2008). In this sense, Colombia is one of the Latin American countries that has had a higher percentage of abstention over time, standing at an average of $53.38 \%$ for the presidential elections in the period 1978 - 2018 (See Figure 1), where In particular, only two years are observed, where the percentage of participation is greater than that of abstention, 1998 and 2018. On the other hand, this indicator is much better in other countries of the world such as the United States (43.3\%), Panama (24.78). \%), Chile (55.39\%), Argentina (24.49\%) or Peru (17.34\%), which shows a much higher percentage of participation, which can be explained by various reasons such as the absence of armed conflict in the other countries and that explains the high participation in the elections of 2018, the first in Colombia after the signing of the peace treaty with the FARC, the obligatory nature of the vote in countries like Chile, a subjectively more consolidated democracy as in the United States, Between other reasons (Center for 
Studies in Democracy and Electoral Affairs, 2013). Among the reasons that explain abstentionism in Colombia and the world, there are social, economic, climatological, geographical and even educational variables, although this phenomenon cannot be studied universally but particularly to each territory (Center for Studies in Democracy and Electoral Affairs, 2013; Lehoucq \& Wall, 2004; Maldonado, 2011; Nohlen et al., 2007). One of the most relevant factors in the high abstention is the geographical location of the polling places because they are not close to the voter, that is why this research seeks to measure the accessibility that citizens have in the city of Manizales and Villamaría to the different voting places arranged in its urban area through the measurement of territorial accessibility along the pedestrian urban network.

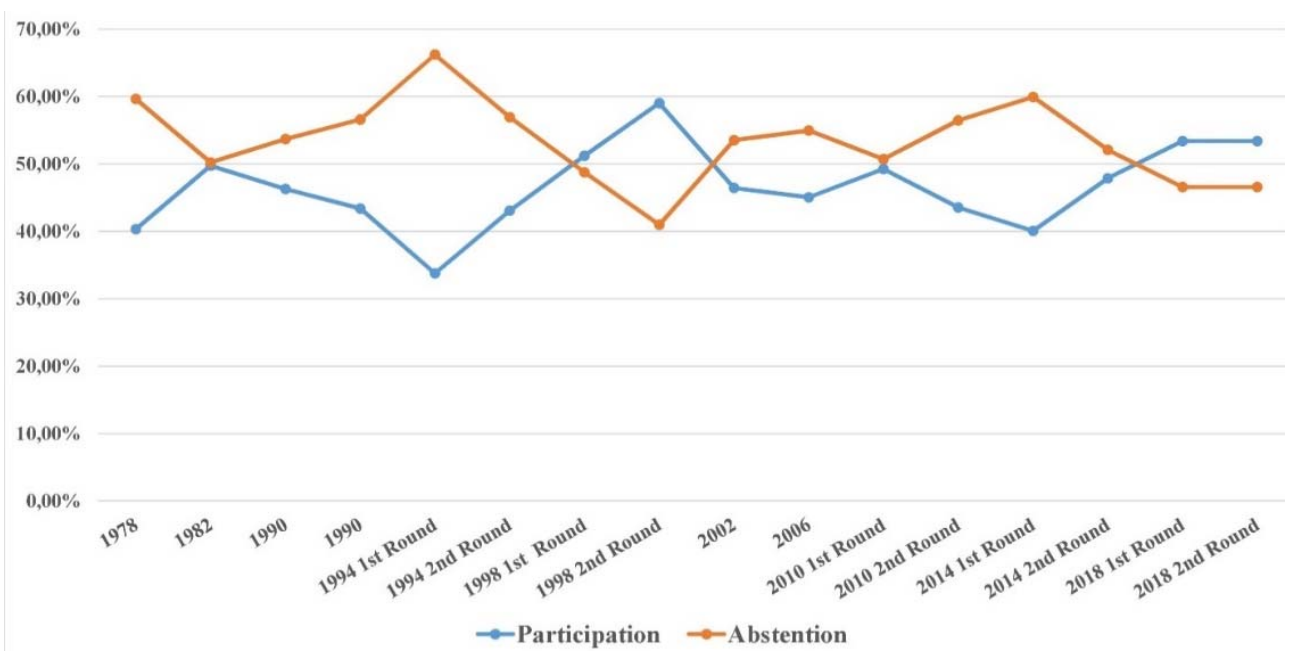

Figure 1. Historical percentage of participation and abstention for presidential elections in Colombia, 1978 2018. Source: Own elaboration based on data obtained from the International Institute for Democracy (IDEA, 2018) and Electoral Assistance, the National Registry of Colombian Civil Status (2018a) and the Electoral Observation Mission (MOE, 2014)

Accessibility is a concept used since the first decades of the last century to explain land-use planning, transport planning, diversification of land uses, among other topics (Batty, 2009, Handy \& Niemeier, 1997). However, it was Hansen (1959) who dared to define it as the potential of opportunities for interaction that the inhabitant of a territory possesses, through a study that used the road network and the jobs offered in Washington D.C. On the other hand, Ingram (1971) defines this concept as an inherent characteristic of a place to overcome a source of friction such as distance or time and is used as an explanation tool for the growth of cities, location of equipment (educational, commercial, security, justice, recreational, etc.) and the combination of land uses. He also introduced a division of concepts in the term. First, relative accessibility is a measure of connection between two points through the road network, while integral accessibility is presented as a measure between multiple nodes versus a few, for example, in a city it is possible to measure the integral accessibility of the citizens against the offered hospital equipment (Escobar, Holguín, \& Zuluaga, 2016). Later, Pirie (1979) listed the different types of calculus present in the concept of accessibility developed over the years by researchers. On the other hand, Handy and Niemeier (1997) indicate how the quality, quantity and nature of the opportunities offered determine the measure as well as the cost of travel due to the fact that the less money and time are spent, the more opportunities can be reached by the people, increasing accessibility in the territory. Then, Geurs and Ritsema Van EcK (2001) raised a series of perspectives and components that make up and complement this important concept. Finally, in recent years efforts have been concentrated on reinforcing the theories previously planted while developing new approaches and applications for the term (Geurs, De Montis, \& Reggiani, 2015; van Wee, 2016).

In this research article, integral accessibility will be used to analyze the accessibility of the inhabitants of Manizales and Villamaría in relation with the polling places offered by the National Registry of the Colombian Civil Status, studying its relationship with the high percentage of electoral abstention that is suffered in democratic participation in Colombia. Manizales (see figure 2), capital of the department of Caldas, is located in the center west of Colombia on the central mountain range at 2150 meters above sea level on average, having a steep territory that makes it difficult for urban settlements and the construction of infrastructure projects (Robledo, 1996). On the other hand, according to the projections of the 2005 census made by the National Administrative Department of Statistics (DANE), for 2017 it has a population of 371307 in its urban area, 
reaching 419943 inhabitants next to the neighboring municipality of Villamaría (DANE, 2010). As for urban mobility, $29 \%$ of its inhabitants use walking as the main mode of travel followed by public transport with $24 \%$, automobile with $14 \%$ and motorcycle with $11 \%$. Also, the main reason for travel is related to work and study, totaling an average of 2.34 trips per man and 1.85 trips per woman, evidencing an inequity in what refers to gender (Alcaldía de Manizales, 2017). Accessibility measures have been used in Colombia and specifically in Manizales as a planning and research method to solve various situations in urban planning and transportation (Escobar, Duque, \& Salas, 2015, Escobar \& Garcia, 2011, Perilla, Escobar, \& Cardona, 2018; Zuluaga \& Escobar, 2017), therefore in this research the use of these methods is enhanced to explain something as important as the relation of the location of the polling stations with the electoral abstention.

After the introduction, the research methodology is presented to later make a discussion of the main results along with the conclusions.

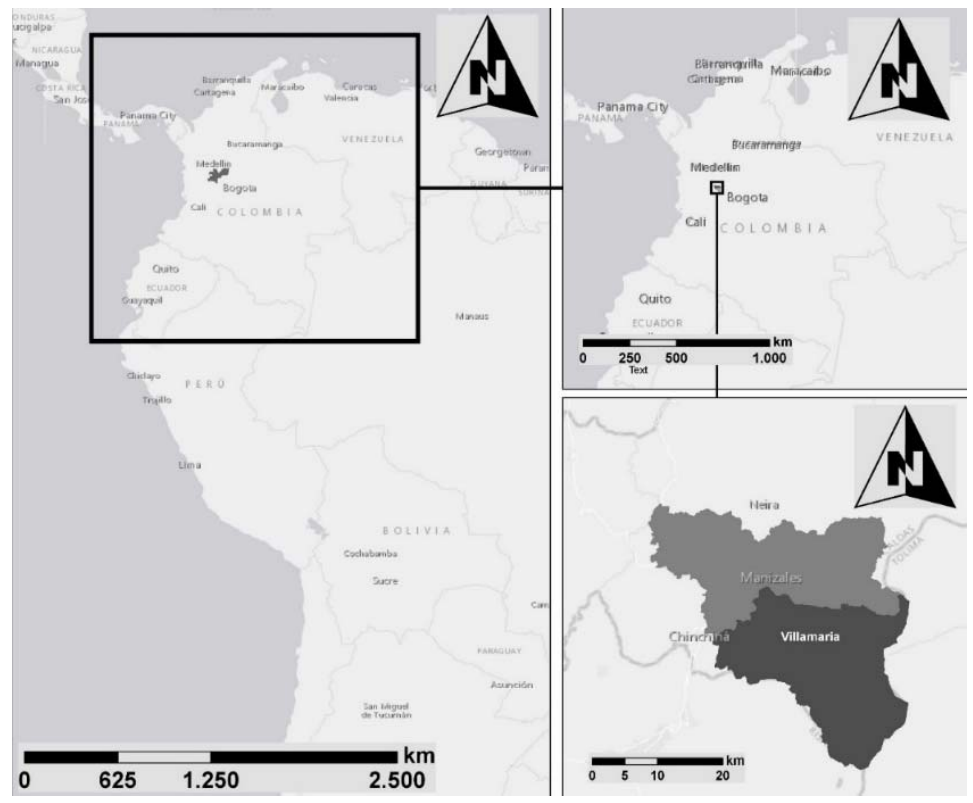

Figure 2. Geographic location of Manizales and Villamaria. Source. Authors

\section{Methodology}

The research methodology (Figure 3) has four (4) consecutive stages that are described below.

\subsection{Stage 1}

The first stage of the investigation consists of the development of the necessary information for the calculations of integral accessibility. Firstly, the urban road network of the municipality of Manizales and Villamaría is obtained together with the neighborhood polygon, both georeferenced in Geographic Information Systems (GIS) software, a product of previous research carried out in the city (Escobar \& Garcia, 2012; Perilla et al., 2018). Likewise, the road network must be complemented with the pedestrian passages present in the city, such as pedestrian bridges, stairs and other steps that connect the different neighborhoods with each other. This will allow the calculation of minimum roads that are made in later stages to be closer to reality (Ortúzar \& Willumsen, 1994). In addition, the travel time per arc must be calculated, which is a relation between the length of the arcs obtained by means of the "Calculate Geometry" tool of ArcGis and the pedestrian speed, established at 4.32 $\mathrm{km} / \mathrm{h}$ according to previous investigations made in the city related to pedestrians (Zuluaga, Escobar, \& Younes, 2018), which may be affected, in some cases, by the slope of the terrain (Urban Development Institute, 2005). On the other hand, the neighborhood polygon should be updated in its population, since the last registered population is dated 2015, so it should be projected according to the indications of the DANE for the year 2017 (DANE, 2010), likewise, taking into account the electoral census for Manizales and Villamaría given by the National Registry of Civil Status for the elections of 2018(Registraduria Nacional del Estado Civil for its name in Spanish) (Registraduria Nacional del Estado Civil, 2018b). 


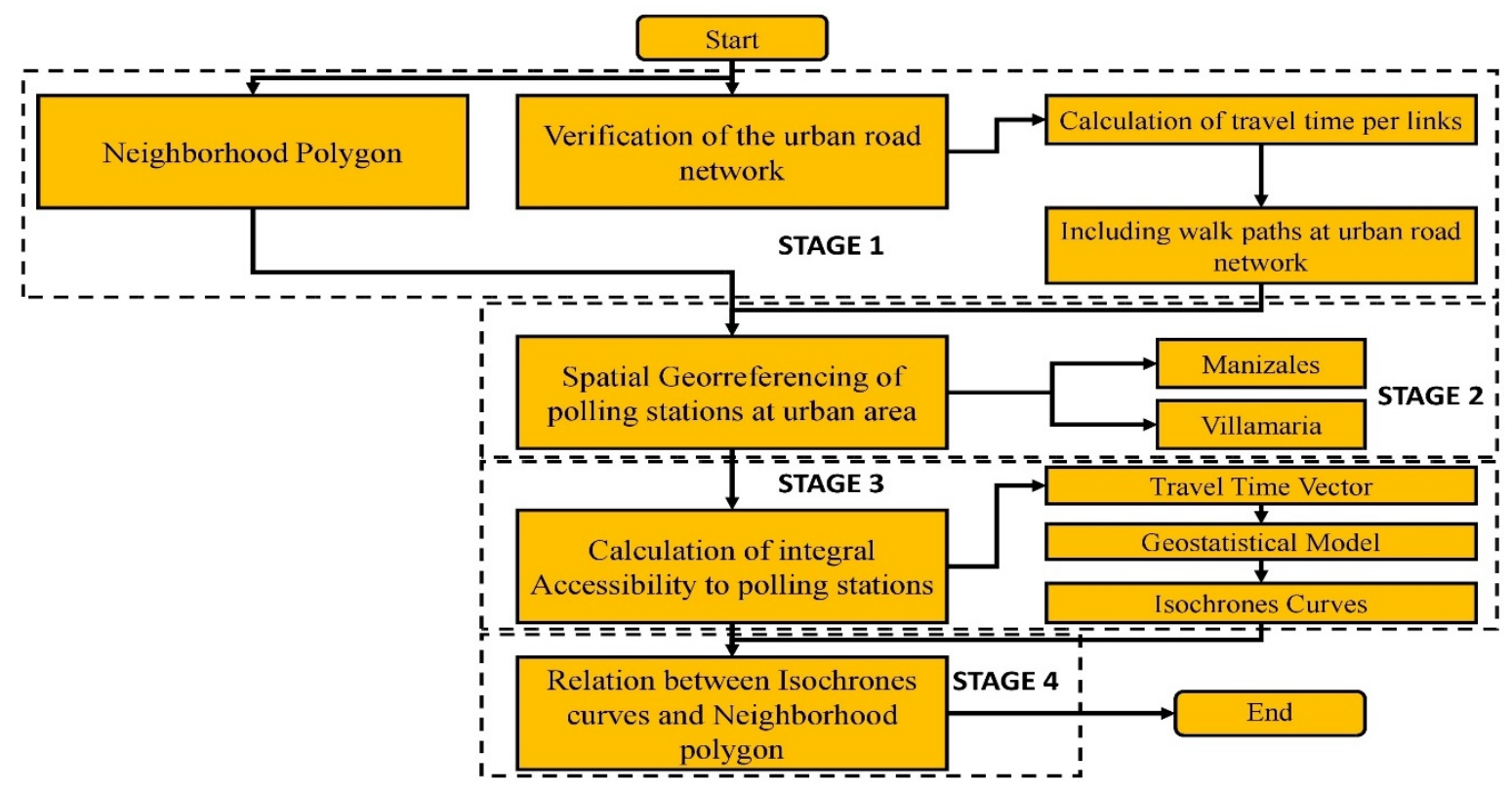

Figure 3. Research Methodology

\subsection{Stage 2}

On this stage, the analyzed voting places that are georeferenced in GIS software. For this, a search must be made on the page of the National Registry of the Colombian Civil Status where it is possible to find the different polling places present throughout the national territory in front of their names, address and electoral potential of men and women (Registraduria Nacional del Estado Civil, 2018c).

\subsection{Stage 3}

To obtain the integral accessibility, the travel time vector must be calculated through the "multiple paths" tool of the TRANSCAD software which calculates all the minimum paths between the given nodes, minimizing the chosen variable through the Dijsktra algorithm, in our case travel time (Dijkstra, 1959; Wu et al., 2012). This research seeks to calculate the minimum path of all nodes in the road network $(10,312)$ to the nodes corresponding to the polling places (60), resulting in a travel time matrix of 10312 x 60 from which the minimum time for each node is extracted, obtaining the vector of minimum travel time paths to the polling places (Cardona, Zuluaga, \& Escobar, 2017; Montoya \& Escobar, 2017).

After obtaining the vector of travel times to the polling places, we use the ordinary Kriging geo-model with semi-linear variogram as the structuring equation, present in the ArcGis software, to obtain the isochronous curves of integral accessibility (Perilla et al., 2018). This geo-statistic model has been present as a predictor model in different investigations related to transport networks (Lindner, Pitombo, Rocha, \& Quintanilha, 2016; Moncada, Cardona, \& Escobar, 2018; Prasetiyowati, Imrona, Ummah, \& Sibaroni, 2016).

\subsection{Stage 4}

On this last stage, it is sought to relate the isochrones curves of integral accessibility to the polling places with the neighborhood polygon of the study area, from where an analysis can be carried out among the population covered by the different curves, differentiating the neighborhoods and strata of the city that obtain a better integral accessibility. The strata are a socio-economic differentiation that is used in Colombia to divide the population groups on a scale from 1 to 6 , where 1 represents the lowest stratum and 6 the highest stratum. This division is based fundamentally on economic and social variables (Perilla et al., 2018).

\section{Results and Discussion}

\subsection{Urban Road Network and Neighborhood Polygon}

Figure 5 shows the 60 polling places located in the urban area of Manizales (54 polling places) and Villamaría (6 polling places). On the other hand, in table 1 there is a list with the names of the 60 polling places next to their 
electoral potential, divided between men and women and their geographical coordinates (latitude and longitude) in the WGS 1984 system. You can see that the voting station with the most voters is the University of Caldas (ID 1) with 17,928 , followed by the Fe y Alegría educational institution (ID 25) with 11,740 voters and the Isabel la catholic Educational Institution ( ID 16) with 11,586 voters. On the other hand, the posts that have fewer voters are the National Men's Prison (ID 8) with 228 voters, the Women's Detention (ID 29) with 47 voters and "the Escuela de Trabajo los Zagales" (ID 10) with 18 voters (See Table 1). The latter correspond to the detention centers for male prisoners, women and minors who, according to a decree issued in 1994, can exercise their right to vote while they are being held but not sentenced.minimum routes and the travel times between nodes which causes that as the distances between nodes are greater, the difference between the scenarios are greater.

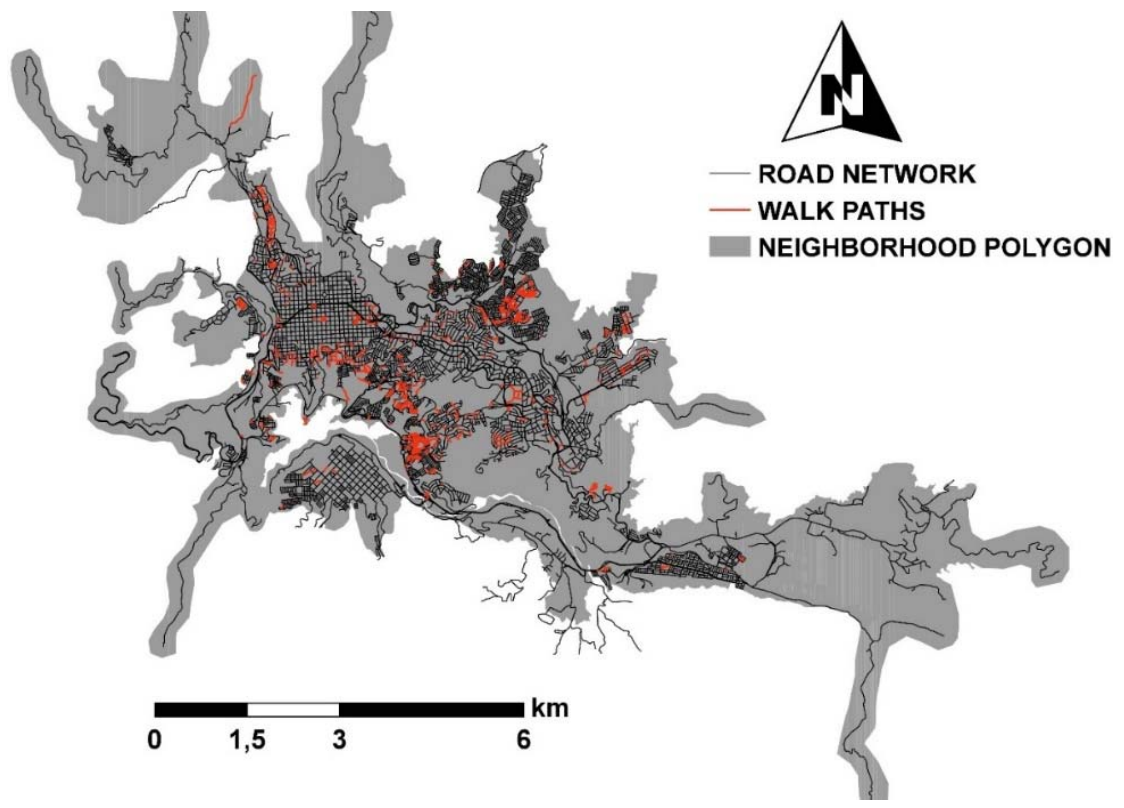

Figure 4. Road Network and Neighborhood Polygon

\subsection{Polling Places}

Figure 5 shows the 60 polling places located in the urban area of Manizales (54 polling places) and Villamaría (6 polling places). On the other hand, in table 1 there is a list with the names of the 60 polling places next to their electoral potential, divided between men and women and their geographical coordinates (latitude and longitude) in the WGS 1984 system. You can see that the voting station with the most voters is the University of Caldas (ID 1) with 17,928, followed by the Fe y Alegría educational institution (ID 25) with 11,740 voters and the Isabel la catholic Educational Institution (ID 16) with 11,586 voters.

On the other hand, the posts that have fewer voters are the National Men's Prison (ID 8) with 228 voters, the Women's Detention (ID 29) with 47 voters and "the Escuela de Trabajo los Zagales" (ID 10) with 18 voters (See Table 1). The latter correspond to the detention centers for male prisoners, women and minors who, according to a decree issued in 1994, can exercise their right to vote while they are being held but not sentenced.minimum routes and the travel times between nodes which causes that as the distances between nodes are greater, the difference between the scenarios are greater. 


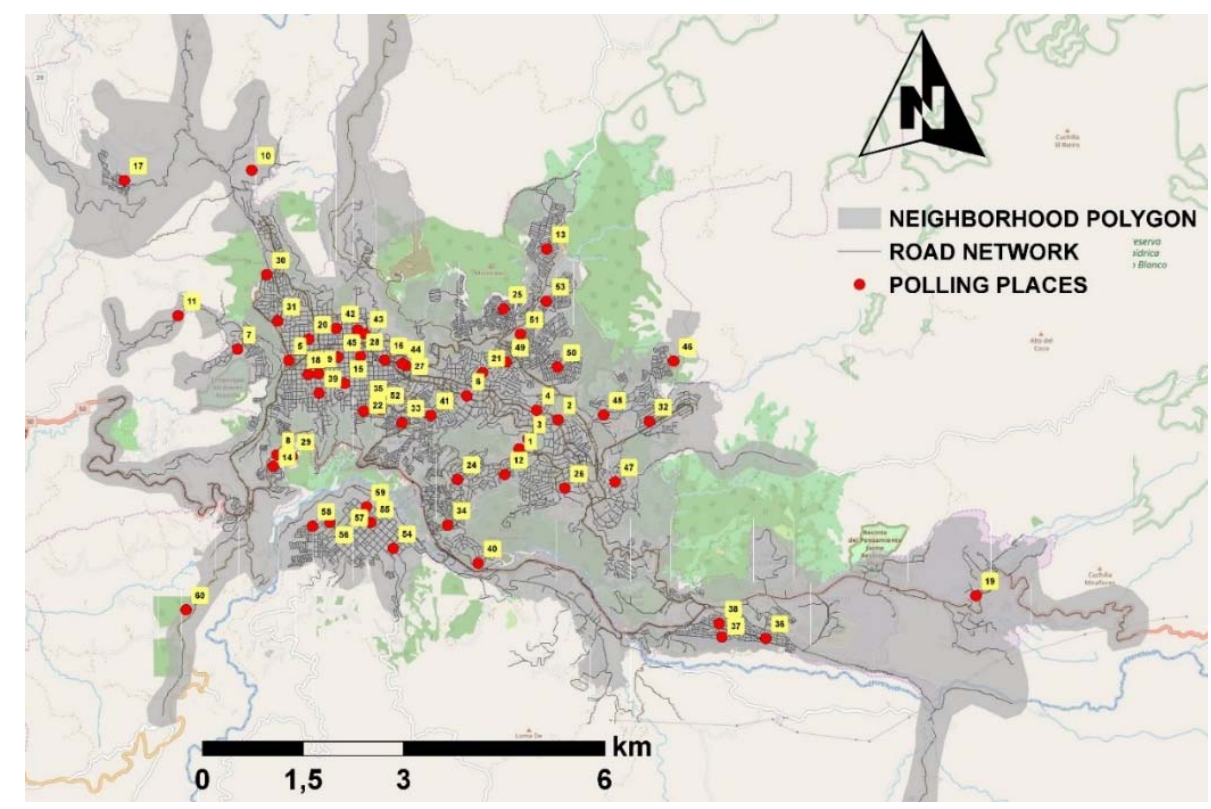

Figure 5. Geographic location of polling stations

Table 1. Name, coordinates and voter base per polling station

\begin{tabular}{|c|c|c|c|c|c|c|}
\hline Id & Name & Latitude & Longitude & Women & Men & Total \\
\hline 1 & Universidad de Caldas & 5.056 & -75.493 & 8649 & 9279 & 17928 \\
\hline 2 & Universidad Católica de Manizales & 5.060 & -75.488 & 2913 & 2424 & 5337 \\
\hline 3 & I. E. Normal Superior de Manizales & 5.057 & -75.492 & 2209 & 2193 & 4402 \\
\hline 4 & Facultad de Ciencias Jurídicas y Sociales & 5.061 & -75.490 & 3398 & 2639 & 6037 \\
\hline 5 & Facultad de Bellas Artes (U. de Caldas) & 5.068 & -75.524 & 2126 & 3879 & 6005 \\
\hline 6 & Facultad de Ciencias Para la Salud (U. de Caldas) & 5.063 & -75.500 & 4099 & 3350 & 7449 \\
\hline 7 & Colegio Filipense de Nuestra Señora de Lourdes & 5.070 & -75.531 & 1674 & 1449 & 3123 \\
\hline 8 & Cárcel Nacional de Varones & 5.055 & -75.525 & 36 & 192 & 228 \\
\hline 9 & Colegio Mayor de Nuestra Señora & 5.066 & -75.520 & 4291 & 5507 & 9798 \\
\hline 10 & Escuela de Trabajo La Linda (Los Zagales) & 5.094 & -75.529 & 5 & 13 & 18 \\
\hline 11 & I. E. Adolfo Hoyos Ocampo & 5.074 & -75.539 & 996 & 949 & 1945 \\
\hline 12 & I. E. Atanasio Girardot & 5.053 & -75.495 & 3333 & 2819 & 6152 \\
\hline 13 & I. E. Bosques del Norte & 5.083 & -75.489 & 4511 & 3573 & 8084 \\
\hline 14 & I. E. Estambul & 5.054 & -75.526 & 2563 & 2055 & 4618 \\
\hline 15 & I. E. Gran Colombia & 5.065 & -75.516 & 3295 & 2706 & 6001 \\
\hline 16 & I. E. Isabel La Católica & 5.068 & -75.511 & 6221 & 5365 & 11586 \\
\hline 17 & I. E. La Linda & 5.092 & -75.546 & 2723 & 2657 & 5380 \\
\hline 18 & I. E. León de Greiff & 5.066 & -75.521 & 3603 & 3619 & 7222 \\
\hline 19 & I. E. Malteria & 5.036 & -75.431 & 644 & 662 & 1306 \\
\hline 20 & I. E. Marco Fidel Suarez & 5.071 & -75.521 & 3036 & 4971 & 8007 \\
\hline 21 & I. E. San Jorge & 5.066 & -75.498 & 5139 & 4029 & 9168 \\
\hline 22 & I. E. Andrés Bello & 5.061 & -75.514 & 3435 & 2789 & 6224 \\
\hline 23 & I. E. Divina Providencia & 5.072 & -75.515 & 1621 & 1334 & 2955 \\
\hline 24 & I. E. Eugenio Pacelli (Sede Principal) & 5.052 & -75.501 & 3906 & 3062 & 6968 \\
\hline
\end{tabular}




\begin{tabular}{|c|c|c|c|c|c|c|}
\hline Id & Name & Latitude & Longitude & Women & Men & Total \\
\hline 25 & I. E. Fe y Alegría La Paz & 5.075 & -75.495 & 6545 & 5195 & 11740 \\
\hline 26 & I. E. Escuela Nacional de Enfermería & 5.051 & -75.487 & 4419 & 3366 & 7785 \\
\hline 27 & I. E. Técnico Fransico José de Caldas & 5.067 & -75.508 & 4287 & 942 & 5229 \\
\hline 28 & Liceo Arquidiocesano de Nuestra Señora & 5.069 & -75.514 & 1876 & 3429 & 5305 \\
\hline 29 & Reclusión de Mujeres Villa Jo. & 5.055 & -75.523 & 45 & 2 & 47 \\
\hline 30 & I. E. Instituto Chipre & 5.080 & -75.527 & 2333 & 1993 & 4326 \\
\hline 31 & I. E. Chipre Sede B & 5.073 & -75.525 & 4968 & 3532 & 8500 \\
\hline 32 & I. E. La Sultana Sede A & 5.060 & -75.475 & 3971 & 2960 & 6931 \\
\hline 33 & I. E. Leonardo Davinci & 5.060 & -75.509 & 5165 & 3888 & 9053 \\
\hline 34 & I. E. Malabar Sede A & 5.046 & -75.502 & 4228 & 3272 & 7500 \\
\hline 35 & I. E. Perpetuo Socorro & 5.062 & -75.512 & 1639 & 1164 & 2803 \\
\hline 36 & I. E. San Pio X & 5.031 & -75.460 & 4133 & 3771 & 7904 \\
\hline 37 & I. E. San Pio X Sede B & 5.031 & -75.465 & 2259 & 1879 & 4138 \\
\hline 38 & I. E. San Pio X Sede A & 5.033 & -75.466 & 2192 & 1674 & 3866 \\
\hline 39 & I. E. Siete de Agosto & 5.064 & -75.520 & 5479 & 4057 & 9536 \\
\hline 40 & I. E. Aranjuez Sede A & 5.041 & -75.498 & 2360 & 2005 & 4365 \\
\hline 41 & I. E. Latinoamericano Sede B & 5.061 & -75.505 & 2095 & 1614 & 3709 \\
\hline 42 & I. E. San Agustín & 5.072 & -75.517 & 1541 & 3164 & 4705 \\
\hline 43 & I. E. Instituto Manizales & 5.072 & -75.514 & 5666 & 3365 & 9031 \\
\hline 44 & I. E. Instituto Universitario de Caldas & 5.068 & -75.509 & 3072 & 2717 & 5789 \\
\hline 45 & Ed. Industria Licorera de Caldas & 5.069 & -75.517 & 4208 & 2822 & 7030 \\
\hline 46 & I. E. Mariscal Sucre Sede B & 5.068 & -75.472 & 1769 & 1414 & 3183 \\
\hline 47 & I. E. Mariscal Sucre Sede A & 5.052 & -75.480 & 2806 & 2143 & 4949 \\
\hline 48 & I. E. Mariscal Sucre Sede D & 5.061 & -75.481 & 2401 & 2033 & 4434 \\
\hline 49 & I. E. La Asunción Sede A & 5.068 & -75.494 & 2783 & 2217 & 5000 \\
\hline 50 & I. E. La Asunción Sede C & 5.067 & -75.488 & 3417 & 2722 & 6139 \\
\hline 51 & I. E. Sinaí Sede B & 5.072 & -75.493 & 4297 & 3287 & 7584 \\
\hline 52 & I. E. Leonardo Davinci Sede A & 5.061 & -75.511 & 1123 & 863 & 1986 \\
\hline 53 & I. E. Liceo Mixto Sinai Sede A & 5.076 & -75.489 & 3328 & 2580 & 5908 \\
\hline 54 & Colegio Villa del Rosario & 5.043 & -75.510 & 2956 & 2230 & 5186 \\
\hline 55 & I.E. San pedro Claver & 5.046 & -75.513 & 3806 & 3528 & 7334 \\
\hline 56 & Escuela Jhon F. Kennedy & 5.046 & -75.518 & 1606 & 2154 & 3760 \\
\hline 57 & I. E. Gerardo Arias Ramírez & 5.045 & -75.516 & 4499 & 3615 & 8114 \\
\hline 58 & Escuela Rafael Pombo & 5.046 & -75.521 & 1644 & 681 & 2325 \\
\hline 59 & Instituto Villamaria & 5.048 & -75.513 & 3573 & 3313 & 6886 \\
\hline 60 & Agroturistico El Tablazo & 5.034 & -75.538 & 2169 & 2131 & 4300 \\
\hline
\end{tabular}

\subsection{Integral Accessibility to Polling Places}

Figure 6 shows the isochrones curves of integral accessibility that the inhabitants of Manizales and Villamaría have to the voting places offered through the pedestrian road network. There can be found travel times from the 0 to 5 minute intervals, which correspond to nodes that are very close to the voting places, few meters so the walking time is minimal. On the other hand, there are travel times of more than 60 minutes and that reach 100 minutes, which represent distances to the polling places above $4 \mathrm{~km}$ and which reaches a maximum of $6.8 \mathrm{~km}$. However, the latter case is only found in urban areas where few inhabitants live according to the density distribution of the neighborhood polygon. 


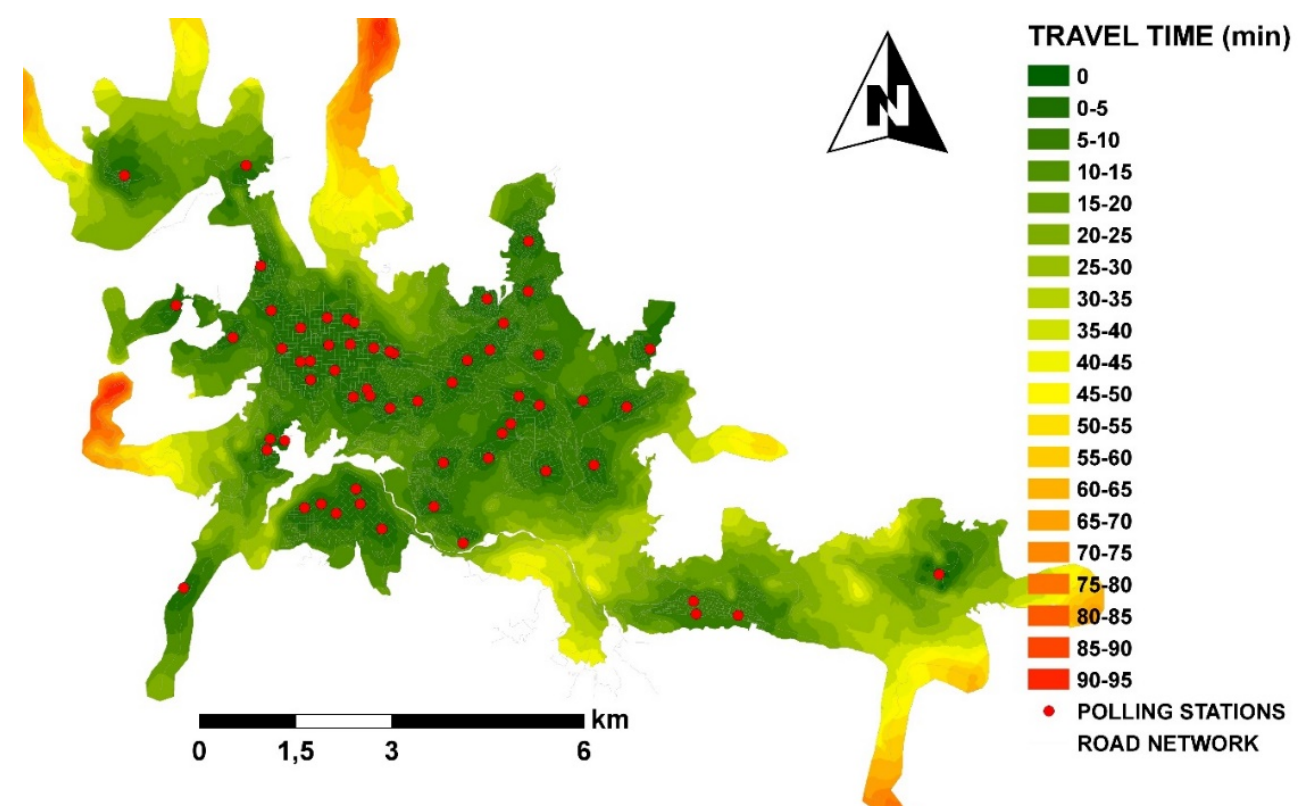

Figure 6. Accessibility to Polling Places

Thus, Figure 7 shows the frequency histogram between the percentage of population and area against the coverage of the isochronous accessibility curves. There can be observed how the interval of 0 to 5 minutes covers $40 \%$ of the electoral census (129 525 people) and the interval of 5 to 10 minutes covers $38 \%$ of the electoral census (121 095 people) which indicates that great percentage of the population, $78 \%$ according to the accumulated coverage ogive (figure 8 ) is covered by travel times by walking to the polling places of 10 minutes or less. Likewise, $96 \%$ of the electoral census (308 413 people) that is covered for less than 20 minutes shows good accessibility by walking to the polling places showing an excellent offer of this type of equipment.

The interesting thing is in the percentage of the population that has more than 20 minutes (4\% equivalent to 14 010 people) since these are times for which the walk is not the first option of transportation to polling places, so that could be a cause for electoral abstention. Although abstentionism in Manizales for the last presidential election of June 17, 2018 reached 39.5\% and for Villamaría 39.86\%, lower percentages were presented in the national average of $47 \%$ (Registraduria Nacional del Estado Civil, 2018a). Therefore, in the urban area there is no direct relationship between the high percentage of abstentionism and the poor coverage accessibility, since as shown above there is a high percentage of the electoral census (96\%) covered by walking times of less than 20 minutes while the participation reached $60 \%$.

Regarding the analysis of population coverage according to socioeconomic strata, it is found that stratum 1, the other low economic resources, has the lowest population coverage for travel times of less than 10 minutes, reaching $45 \%$ coverage. While for the other strata this percentage is higher than $70 \%$, reaching $84 \%$ coverage for the neighborhoods belonging to stratum 2. Likewise, stratum 1 reaches $88 \%$ coverage for times less than 20 minutes, a percentage that for the total urban area is $96 \%$ and for the other strata, it is over $90 \%$. So it can be said that there is an inequity in the supply of equipment for the stratum 1 neighborhoods (See Figure 9). 


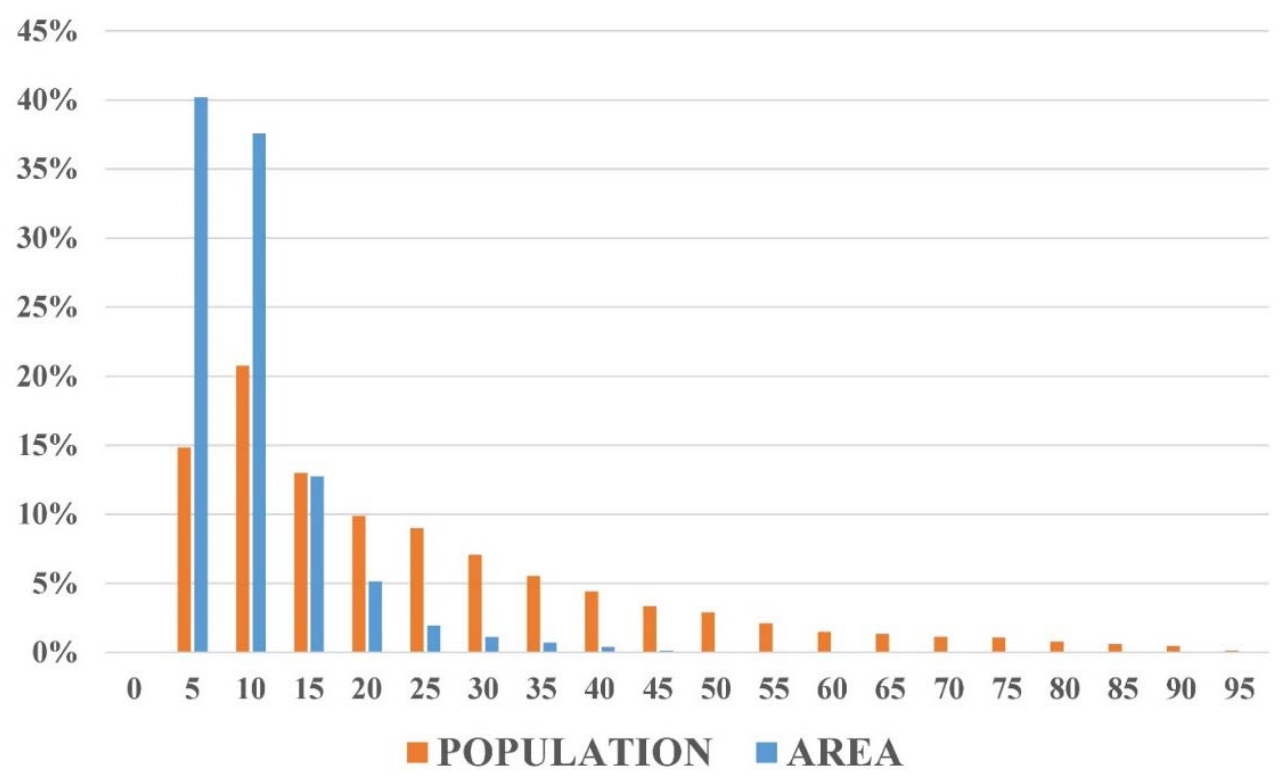

Figure 7. Histogram of coverage of area and population

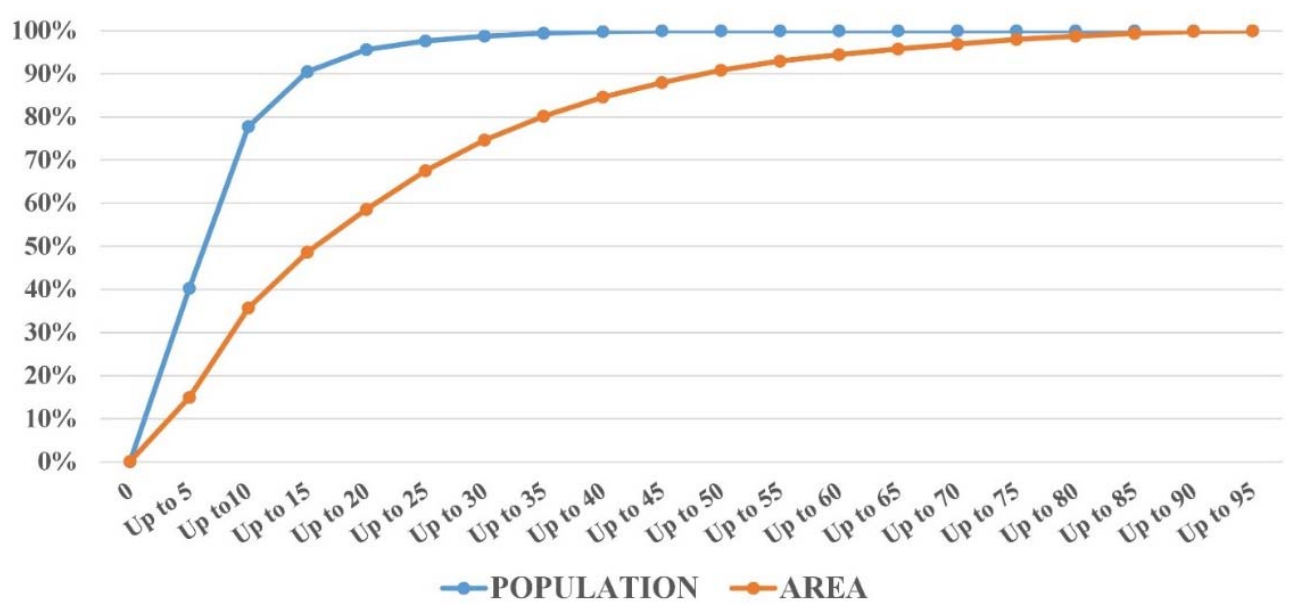

Figure 8. Relation between percentage of covered population and area and isochrones

\section{Conclusions}

Colombia has an imperfect democracy, according to the "Democracy Index 2017" made by The Economist Intelligence Unit, which measures the quality of democracy in 167 countries around the world through surveys conducted on the population and analyzed by international experts on the subject of democracy. In this sense, Colombia reaches an overall score of 6.67 , between 1 and 10 , where 10 indicates a full democracy, where the worst indicator suggests political participation among what represents the high percentage of historical abstentionism that has been presented, which is why advancing in this aspect is fundamental to improve the quality of Colombian democracy.

Abstentionism happens due to several reasons among which we can find the deficiency in the offer of polling places so the calculation of the integral accessibility to the polling places through by walking can envision a picture of the coverage that polling places have in the cities of the country so measures can be taken of where to locate new polling places or transport infrastructure that should be improved to increase coverage and thus reduce voter abstentionism. 


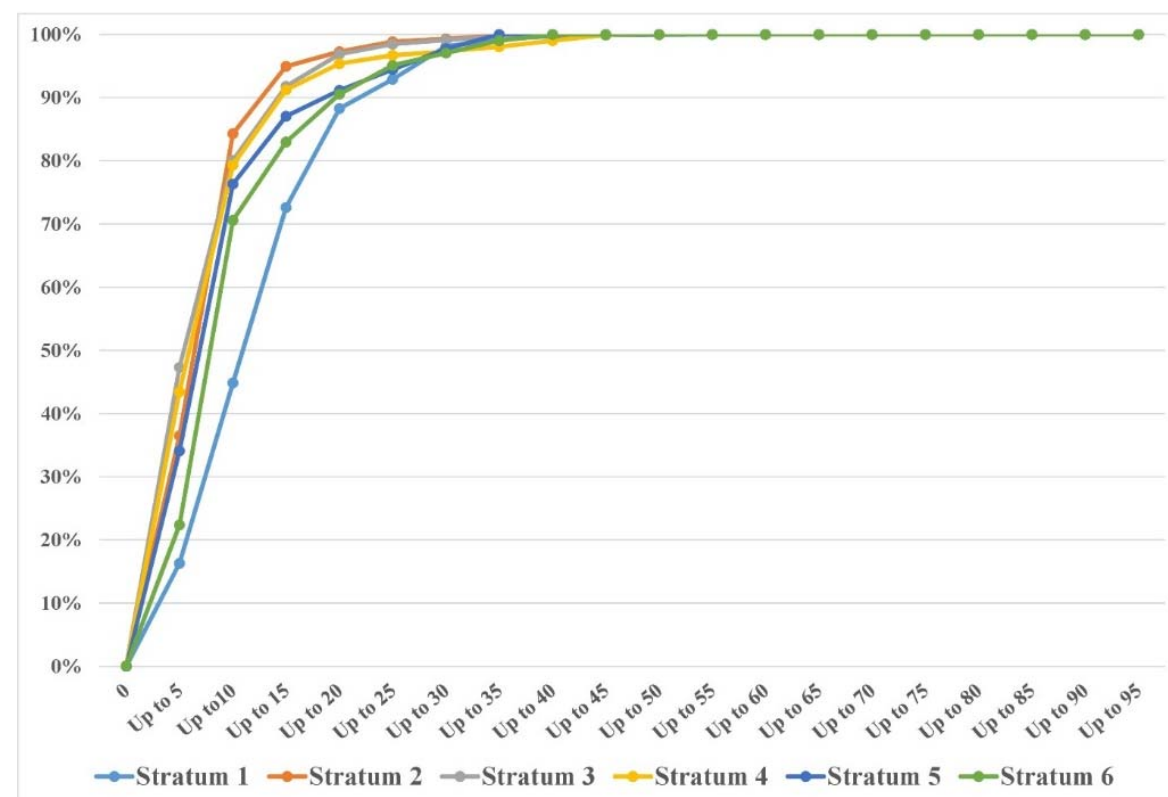

Figure 9. Relation between percentage of covered population, isochrones curves and socio economic strata

Manizales and Villamaría have a participation percentage higher than the national average although the percentage of participation for the last election (over 60\%) does not come close to the great percentage of coverage they have in terms of the polling places since they reach a coverage of $96 \%$ of the electoral census for less than 20 minutes by walking, which indicates good accessibility and a good offer of electoral equipment. It is important that for the next elections the percentage of coverage of the polling places reaches $100 \%$ for travel times of less than 20 minutes, so that the distance of the polling places is not a reason for electoral abstentionism.

According to the strata analysis, the coverage of the neighborhoods belonging to stratum 1 should be improved in order to increase the general accessibility to the voting places. Locating new polling places in these neighborhoods will make the general coverage grow, benefiting a larger percentage of the population and decreasing voter abstentionism.

\section{Acknowledgments}

The researchers would like to thank the students of the research group on sustainable urban mobility at the Universidad Nacional de Colombia - Sede Manizales, particularly at Sergio Idarraga Gonzáles Civil Engineer degree student, for their collaboration in the georeferencing of the polling places.

\section{References}

Alcaldía de Manizales. (2017). Plan Maestro de Movilidad de Manizales: Línea base y diagnóstico de la situación actual de la movilidad de Manizales. Manizales.

Alcántara, M. (2008). Luces y sombras de la calidad de la democracia en América Latina. Quórum. Revista de Pensamiento Iberoamericano, (22), 169-181.

Batty, M. (2009). Accessibility: In search of a unified theory. Environment and Planning B: Planning and Design, 36(2), 191-194. http://doi.org/10.1068/b3602ed

Cardona, M., Zuluaga, J. D., \& Escobar, D. A. (2017). Análisis de la red de ciclo-rutas de Manizales (Colombia) a partir de criterios de accesibilidad territorial urbana y cobertura de estratos socioeconómicos. Revista Espacios, 38(28).

Center for Studies in Democracy and Electoral Affairs-Centro de Estudios en Democracia y Asuntos Electorales. (2013). Abstencionismo electoral en Colombia : una aproximación a sus causas. Registraduría Nacional del Estado Civil. Bogota.

Departamento Administrativo Nacional de Estadística - DANE (2010). Proyecciones de población total por sexo y grupos de edad de 0 hasta 80 y más años $(2005$ - 2020). Retrieved from http://www.dane.gov.co/index.php/estadisticas-por-tema/demografia-y-poblacion/proyecciones-de-poblacio 
n

Dijkstra, E. W. (1959). A note on two problems in connexion with graphs. Numerical Mathematics, 1(1), 269-271. https://doi.org/10.1007/BF01386390

Electoral Observation Mission - Misión de Observación Electoral. (2014). Resultados Elecciones Presidenciales Primera Y Segunda Vuelta 2014.

Escobar, D. A., Duque, J. P., \& Salas, A. (2015). Accesibilidad como herramienta de planeación urbana. Caso de estudio : Redireccionamiento vial en Riosucio (Caldas - Colombia). Avances Investigación En Ingeniería, 11(2), 9-18.

Escobar, D. A., \& Garcia, F. (2011). Impacto de un sistema de transporte tipo Cable sobre la movilidad urbana. Caso Manizales (Colombia). Avances Investigación En Ingeniería, 8(1), 92-98. Retrieved from http://www.unilibre.edu.co/revistaavances/avances-8-1/r8-1_art11.pdf

Escobar, D. A., \& Garcia, F. (2012). Diagnóstico de la Movilidad Urbana de Manizales (Primera ed). Manizales.

Escobar, D. A., Holguín, J. M., \& Zuluaga, J. D. (2016). Accesibilidad de los centros de ambulancias y hospitales prestadores del servicio de urgencias y su relación con la inequidad espacial. Caso de estudio Manizales Colombia. Revista Espacios, 37(20), 20.

Geurs, K. T., De Montis, A., \& Reggiani, A. (2015). Recent advances and applications in accessibility modelling. $\begin{array}{lllll}\text { Computers, } \quad \text { Environment } & \text { and }\end{array}$ http://doi.org/10.1016/j.compenvurbsys.2014.09.003

Geurs, K. T., \& Ritsema van Eck, J. (2001). Accessibility measures: review and applications. Evaluation of accessibility impacts of land-use transportation scenarios, and related social and economic impact. RIVM Report, 787, 1-265. Retrieved from https://rivm.openrepository.com/rivm/handle/10029/9487

Handy, S. L., \& Niemeier, D. A. (1997). Measuring Accessibility: An Exploration of Issues and Alternatives. Environment and Planning A, 29(7), 1175-1194. http://doi.org/10.1068/a291175

Hansen, W. G. (1959). How Accessibility Shapes Land Use. Journal of the American Institute of Planners, 25(2), 73-76. http://doi.org/10.1080/01944365908978307

Ingram, D. R. (1971). The Concept of Accessibility: A search for an operational form. Regional Studies, 5(2), 101-107. http://doi.org/http://dx.doi.org/10.1080/09595237100185131

International Institute for Democracy - Instituto Internacional para la Democracia-IDEA (2018). Population | International IDEA. [Online] Available at: https://www.idea.int/data-tools/question-countries-view/447/82/ctr [Accessed 1 Jun. 2018].

Lehoucq, F., \& Wall, D. L. (2004). Explaining voter turnout rates in new democracies: Guatemala. Electoral Studies, 23(3), 485-500. http://doi.org/10.1016/S0261-3794(03)00055-6

Levine, D. H., \& Molina, J. E. (2007). La Calidad de la Democracia en América Latina: Una Visión Comparada. America Latina Hoy, (45), $\quad$ 17-46. $\quad$ Retrieved from http://www.redalyc.org/articulo.oa?id=30804502\%0ACómo

Lindner, A., Pitombo, C. S., Rocha, S. S., \& Quintanilha, J. A. (2016). Estimation of transit trip production using Factorial Kriging with External Drift: an aggregated data case study. Geo-Spatial Information Science, 19(4), 245-254. http://doi.org/10.1080/10095020.2016.1260811

Maldonado, A. (2011). Compulsory voting and the decision to vote. Americas Barometer Insights, (63), 1-9.

Montoya, J., \& Escobar, D. (2017). Propuesta de ubicación de nuevos centros comerciales, aplicación de un análisis de accesibilidad territorial urbana. Revista Espacios, 38(51).

Moncada, C. A., Cardona, S., \& Escobar, D. A. (2018). Saving Travel Time as an Urban Planning Instrument. Case Study: Manizales, Colombia. Modern Applied Science, 12(6), 44-57. http://doi.org/10.5539/mas.v12n6p44

Nohlen, D. (2004). La participación electoral como objeto de estudio. Elecciones, 3, 137-157. Retrieved from http://www.web.onpe.gob.pe/modEscaparate/caratulas/nohlen2.pdf

Nohlen, D., Zovatto, D., Orozco, J., \& Thompson, J. (2007). Tratado de derecho electoral comparado de américa latina.

Ortúzar, J. de D., \& Willumsen, L. G. (1994). Modelling Transport (4th Ed). John Wiley \& Sons, Ltd. 
http://doi.org/10.1002/9781119993308

Perilla, D. J., Escobar, D. A., \& Cardona, S. (2018). New Transportation Infrastructure Impact in Terms of Global Average Access - Intersection "La Carola" Manizales (Colombia) Case Study. Contemporary Engineering Sciences, 11(5), 215-227. http://doi.org/https://doi.org/10.12988/ces.2018.812

Pirie, G. H. (1979). Measuring Accessibility: A Review and Proposal. Environment and Planning A, 11(3), 299-312. http://doi.org/10.1068/a110299

Prasetiyowati, S. suryani, Imrona, M., Ummah, I., \& Sibaroni, Y. (2016). Prediction of Public Transportation Occupation Based on Several Crowd Spots Using Ordinary Kriging Method. Journal of Innovative Technology and Education, 3(1), 93-104. http://doi.org/http://dx.doi.org/10.12988/jite.2016.6723

Registraduría Nacional del Estado Civil (2018a). Historico de Resultados. [Online] Registraduria Nacional del $\begin{array}{llllll}\text { Estado Civil. } & \text { Retrieved } & \text { May } & 30, & 2018, & \text { from }\end{array}$ https:/wsr.registraduria.gov.co/-Historico-de-Resultados,3635-.html

Registraduría Nacional del Estado Civil (2018b). 782.862 COLOMBIANOS ESTÁN HABILITADOS EN CALDAS PARA VOTAR EN LA ELECCIÓN DE PRESIDENTE Y VICEPRESIDENTE DE 2018. [Online] Registraduria Nacional del Estado Civil. Retrieved May 30, 2018, from https://wsr.registraduria.gov.co/782-862-colombianos-estan.html

Registraduría Nacional del Estado Civil (2018c). EN CALDAS HAY 246 PUESTOS INSTALADOS PARA QUE LOS CIUDADANOS INSCRIBAN SU CÉDULA DE CIUDADANÍA HASTA ESTE DOMINGO 22 DE MAYO. [Online] Registraduria Nacional del Estado Civil. Retrieved May 30, 2018, from https://wsr.registraduria.gov.co/782-862-colombianos-estan.html

Robledo, J. E. (1996). La Ciudad de la Colonización Antioqueña. (Universidad Nacional de Colombia, Ed.) (Primera Ed). Manizales.

Urban Development Institute - Instituto de Desarrollo Urbano. (2005). Guia práctica de la movilidad peatonal urbana. Retrieved from http://www.pactodeproductividad.com/pdf/guiageneralsobreaccesibilidad.pdf

The Economist Intellingence Unit. (2017). Democracy Index 2017 Free speech under attack. The Economist. Retrieved from http://pages.eiu.com/rs/753-RIQ-438/images/Democracy_Index_2017.pdf

van Wee, B. (2016). Accessible accessibility research challenges. Journal of Transport Geography, 51, 9-16. http://doi.org/10.1016/j.jtrangeo.2015.10.018

Wu, L., Xiao, X., Deng, D., Cong, G., Zhu, A. D., \& Zhou, S. (2012). Shortest path and distance queries on road networks: An experimental evaluation. Proceedings of the VLDB Endowment, 5(5), 406-417. http://doi.org/10.14778/2140436.2140438

Zuluaga, J. D., \& Escobar, D. A. (2017). Geomarketing Analysis for Shopping Malls in Manizales (Colombia). Accessibility approach methodology. Revista Espacios, 38(21), 20.

Zuluaga, J. D., Escobar, D. A., \& Younes, C. (2018). A GIS approach based on user location to evaluate a bike-sharing program. DYNA (Colombia), 85(204), 257-263. http://doi.org/10.15446/dyna.v85n204.67670

\section{Copyrights}

Copyright for this article is retained by the author(s), with first publication rights granted to the journal.

This is an open-access article distributed under the terms and conditions of the Creative Commons Attribution license (http://creativecommons.org/licenses/by/4.0/). 